\title{
Mellommenneskelige problemer hos pasienter i psykiatrisk helsevern
}

\author{
Selvrapportering av mellommenneskelige problemer før behandlings- \\ start kan gi viktige bidrag til diagnostikk og behandling.
}

Mellommenneskelige relasjoner har stor betydning for psykisk helse. Det best validerte psykometriske verktøyet for måling av mellommenneskelige problemer er Inventory of Interpersonal Problems (IIP-64), som består av 64 spørsmål. Det er relativt teorinøytralt og forenlig med både biologiske, kognitive, atferdsmessige og psykodynamiske teorier omkring psykiske lidelser.

I min doktorgradsavhandling har jeg undersøkt spørreskjemasvarene til nærmere 1000 polikliniske pasienter. De fleste $(57 \%)$ sliter med problemer knyttet til lav selvhevdelse. De terapeutiske utfordringene er størst hos pasienter som har problemer med å være for dominerende, fiendtlig eller avvisende (28\%) i forhold til andre. Disse pasientene kan lett oppfattes som utakknemlige og ubehagelige og risikerer avvisning fra terapeuten.
I tillegg til mellommenneskelige problemer ble psykiske symptomer og selvbilde undersøkt, og det ble påvist spesifikke sammenhenger mellom visse typer mellommenneskelige problemer på den ene siden og visse typer symptomer og selvbilde på den annen.

I avhandlingen konkluderer jeg med at selvutfyllingsskjemaet Inventory of Interpersonal Problems er nyttig og anvendelig i poliklinisk praksis. Det gir også dimensjonale variabler som kan supplere kategorisk klinisk diagnostikk og mulighet for målinger av behandlingseffekt underveis og etter avsluttet behandling. Brukerperspektiv og kvalitetssikring er også ivaretatt gjennom mer rutinemessig bruk av selvutfyllingsskjema.

\section{Espen Bjerke}

espen.bjerke@so-hf.no

\section{X-bundet adrenoleukodystrofi i Norge}

\section{X-bundet adrenoleukodystrofi er en sjelden genetisk tilstand som det har vært forsket lite på i Norge.}

Tilstanden affiserer spesielt nervesystemet og binyrebarken, særlig hos menn. Det har vært forsket lite på hvordan kvinner med genfeilen rammes. Forekomsten i Norge var ukjent, men tall fra internasjonal litteratur passet dårlig med det vi visste om den norske populasjonen.

I mitt doktorgradsarbeid samlet jeg informasjon om alle norske pasienter med Xbundet adrenoleukodystrofi. Vi fant 63 individer fra 22 separate slekter, og fastsatte prevalensen av tilstanden i Norge (begge kjønn) til 0,8 per 100000 . Årlig blir det født ca. ett barn med X-bundet adrenoleukodystrofi i Norge. Hos kvinnene økte symptomutviklingen med alder. Laboratoriemessige tegn til affeksjon av tynne nervefibre ble funnet uavhengig av kjønn og alder. Overraskende mange slekter hadde de novo-mutasjoner i $A B C D 1$-genet.

Våre funn kan tyde på at X-bundet adrenoleukodystrofi er noe sjeldnere enn antatt.
Vi fant at penetransen hos kvinner er aldersavhengig og at den asymptomatiske tilstanden først og fremst finnes hos de yngste pasientene. Dette er viktig for oppfølging og terapeutiske valg for disse pasientene. Den høye forekomsten av de novo-mutasjoner kan ha betydning for om man skal screene for Xbundet adrenoleukodystrofi hos nyfødte. Tradisjonell familieutredning vil ikke fange opp alle pasientene i den viktige presymptomatiske fasen der vi kan tilby behandling med benmargstransplantasjon.

Funnet av tynnfiberaffeksjon hos de fleste av pasientene kan ha betydning for vår forståelse av patogenesen ved X-bundet adrenoleukodystrofi og for symptomer som smerter og sfinkterforstyrrelser, som er vanlig hos de voksne pasientene.

\section{Morten Andreas Horn}

HORMOR@ous-hf.no

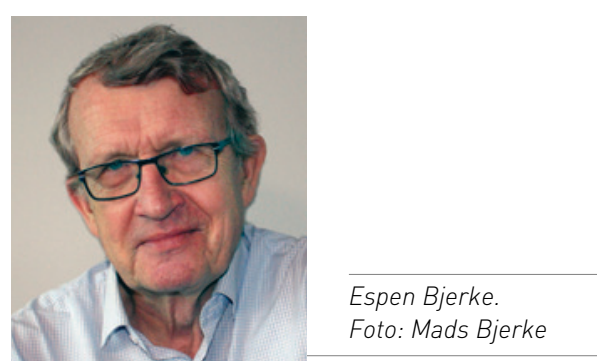

Disputas

Espen Bjerke disputerte for ph.d.-graden ved Universitetet i Oslo 8.4. 2016. Tittelen på avhandlingen er Interpersonal problems among psychiatric outpatients. A study of interpersonal problems and their associations with symptoms and forms of self-relatedness.

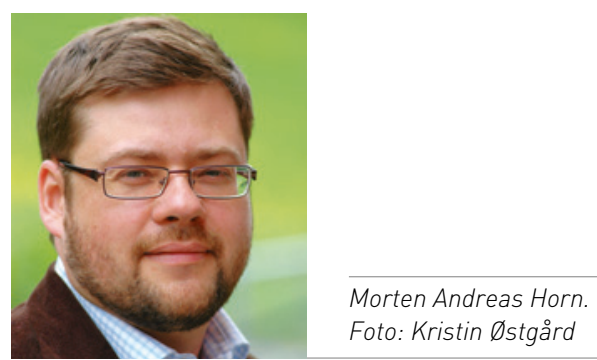

Disputas

Morten Andreas Horn disputerte for ph.d.graden ved Universitetet i Oslo 21.1. 2016. Tittelen på avhandlingen er $X$-linked adrenoleukodystrophy in Norway: Clinical and epidemiological aspects. 